Wells, June, 1914; Westwell, July 4th, 1914 ; Canterbury, June 14th, 1912.

Rhizobius pini, Burmeister.-A white aphid at the roots of various Pinus was found in 1914 and 1915 in March, and April and on into May, which comes very near Hartig's Pemphigus picea. I feel sure that this is Rhizobius pini of Burmeister, the antennæ being shorter than in Pemphigus picea, Hartig.

On spruce roots I have also found a bright green aphid covered with white wool, which is evidently an undescribed species of Rhizobius. It was doing considerable damage to some nursery plants at Wye during the winter 1914-1915, the ground, when the spruce were lifted, being quite white from the quantity of woolly substance they had secreted. This will shortly be describea under the specific name viridis.

\title{
FOUR NEW ENCYRTIDS FROM SICILY AND THE PHILIPPINES.
}

\section{By A. A. Girault.}

\section{Paraleptomastix abnormis, n. sp.}

Female.-Length, $1.00 \mathrm{~mm}$.

Differs from the description of the genotype in being like species of Leptomastix, except that the postmarginal vein is elongate, a third longer than the slender stigmal, and over thrice the length of the marginal, the latter barely twice longer than wide.

Golden yellow-often dusky yellow--marked with dusky black as follows: Distal half to two-thirds of the abdomen, bulb of scape, cephalic aspect of the last two pairs of coxæ; funicles 1 and 2, club, proximal two-thirds of pedicel above, a conspicuous streak along the dorsal scape for its entire length, dorso-lateral edge; and frequently the entire disk of pronotum and scutum. Rest of antennæ pallid dusky, the scape, abdomen, pedicel, pro- and mesopleurum silvery. Propodeum blackish except laterad of the spiracle. Venation dusky. Apex of caudal wing and a longitudinal oblique streak opposite the submarginal vein, dusky. Fore wing conspicuously trifasciate, the first cross-stripe smallest, incomplete, obliqued caudo-proximad from before the bend of the submarginal vein; the second is complete, broader caudad, from the postmarginal vein; the third is largest, across just before the apex, not very broad, divided at middle narrowly and obscurely by a less dusky streak. Pedicel somewhat longer than wide at apex, somewhat shorter than funicle 1 , which is two and a-half times longer than wide; funicles 3 and following each being somewhat longer than 1 . Club joints subequal to the pedicel. Head densely scaly punctate. Axillæ with a short carina between them. Scrobes distinct, not joined above. Dorsal thorax with a short silvery pubescence.

The male is about the same, but the third or distal stripe of the 
fore wing may be nearly absent, usually distinct. The scape is more compressed, the pedicel barely longer than wide, the club solid, the flagellar joints (excluding the pedicel) all somewhat longer and with scattered, rather long hairs, the funicle joints shorter than the club.

Described from a series of specimens reared from Pseudococcus citri. Sicily. Calif. State Insectary. 700 xv. H. S. Smith.

Types.-Catalogue No. 19409, U.S.N.M.; a female and a male on slides; two paratype females on tags.

\section{Epidinocarsis pseudococci, n. sp.}

Female.-Length, $1.50 \mathrm{~mm}$.

Dull orange-yellow, the wings hyaline and like Blastoihrix yucca, Coquillett, but the apex of funicle 1 is white, and the head is entirely yellow except the occiput (vertex dusky in the other species); also over the distal half of the pedicel is white, funicle 6 is barely longer than wide (longer in yucca, where only the distal fourth of the pedicel is white); the funicle joints are all somewhat shorter, the stigmal vein is straighter, longer than the marginal, the postmarginal subobsolete (in yucсa the stigmal vein is more curved, shorter, subequal to the marginal, the postmarginal distinct, acuminate, somewhat shorter than the stigmal); the hairless line in yucca is much less definitely limited. Also in yucce the axillæ are joined with a carina between them; here they are separated for some little distance (but may be occasionally as in yucca). Also in this species only the median line of the scutellum is black (all in yucce except lateral and apical margins). Scrobes distinct, rather long.

The male is smaller and all black, except base of scape and the legs (except coxæ). In the male the marginal vein is subquadrate, the head flatter, the antennæ 9-jointed, the scape's dilation not great, the pedicel globular; flagellum dusky white except pedicel; funicle 1 nearly thrice longer than wide, shorter than the club, the flagellum with rather thick, scraggly hairs. Axillæ joined.

Described from three males and eight females, reared from Pseudococcus citri. Sicily, 1913, H. J. Quayle.

Types.-Catalogue No. 19410, U.S.N.M.; four females on tags, a female and a male head on a slide. Four of the females are paratypes.

\section{Neanastatus orientalis, n. sp.}

Female.-Length, $3.00 \mathrm{~mm}$. The head is lenticular in this genus.

Dark metallic purple, the fore wings deeply infuscated from a little beyond the base of the hairless line distad to apex (deepest under the stigmal and postmarginal veins). Abdomen with a yellowish-white cinctus at base. Head, pronotum except all margins narrowly, antennæ and legs (except the hind legs) golden yellow; proximal joint of hind tarsi white, rest black. Distal four tarsal joints of middle legs black. Mandibles tridentate. Funicle elongate, slender, over twice the length of the not long pedicel, narrowed at proximal third; funicle 2 somewhat shorter, four times longer than wide; 5 slightly longer than wide. Club subequal in length to 
funicle 1. In my table to the Australian species runs to maximicorpus, but differs in coloration. Body scaly. Hind tibial spur black.

From one female on a tag in U.S.N.M., labelled "Manila, P. I. Robt. Brown."

Type.-Catalogue No. 19411, U.S.N.M. ; the above specimen plus a slide with the head, pair of wings, and hind tibiæ.

\section{Neanastatus philippinensis, n. sp.}

Female.-Differs from the preceding in having the body (excluding appendages) entirely dark purple, except the band about the abdomen and the following: The proximal two joints of the hind tarsi are white; all of middle tarsi are yellow, like the first two pairs of legs; the antennæ are purple, and the infuscation of the fore wing is more accented under the distal venation. Head scaly.

From one female taken with the preceding.

Type.-Catalogue No. 19412, U.S.N.M.; the fore-described female on a tag.

\section{THE REARING OF LARVÆ. \\ By C. Rippon, M.A., F.E.S.}

(Concluded from p. 169.)

Quite a number of species which hybernate as larvæ in nature can be made in confinement to feed straight up, pupate and emerge about Christmas or early in the New Year. The two necessary factors are warmth and suitable food. Some larvæ, such as those of Triphana fimbria, will cheerfully accommodate themselves to cabbage leaves when the more usual foodplants are not obtainable; while potatoes, carrots, \&c., are often useful as food substitutes during the cold weather. A suitable temperature is of course all-important, and it should on no account be allowed to drop very low even for a short period. One really cold night will start some larvæ bybernating, and nothing will then induce them to resume feeding. This forcing through of hybernating larvæ is only possible with certain species; others, whether kept warm or not, utterly refuse to go on feeding after a certain period of the autumn. With many hybernating larvæ it is not particularly difficult to bring them through the winter; but the problem is how to prevent them dying off when hybernation is over, which they often persist in doing, despite being supplied with the most tempting portions of their food-plant. When the latter is available sufficiently early, I have found that the best plan is to bring the larvæ into a warm, steady temperature about a month or more before they thoroughly wake up under natural conditions. I often begin to bring in hybernating larvæ in February with most excellent 


\section{$2 \mathrm{BHL}$ Biodiversity Heritage Library}

Girault, Alexandre Arsène. 1915. "Four new encyrtids from Sicily and the Philippines." The Entomologist 48, 184-186.

https://doi.org/10.5962/bhl.part.28222.

View This Item Online: $\underline{\text { https://www.biodiversitylibrary.org/item/42376 }}$

DOI: https://doi.org/10.5962/bhl.part.28222

Permalink: https://www.biodiversitylibrary.org/partpdf/28222

\section{Holding Institution}

Smithsonian Libraries

\section{Sponsored by}

Smithsonian

\section{Copyright \& Reuse}

Copyright Status: NOT_IN_COPYRIGHT

This document was created from content at the Biodiversity Heritage Library, the world's largest open access digital library for biodiversity literature and archives. Visit BHL at https://www.biodiversitylibrary.org. 